\title{
Functional characteristics of intraepithelial lymphocytes from mouse small intestine III. Inability of intraepithelial lymphocytes to induce a systemic graft-versus-host reaction is because of failure to migrate in vivo
}

\author{
MARIA E BACA, A MCI MOWAT, SHEILA MACKENZIE, \\ AND DELPHINE M V PARROTT \\ From the Department of Bacteriology and Immunology, Western Infirmary, Glasgow
}

SUMMARY In this study we have investigated whether addition of bone marrow accessory cells or concurrent administration of recombinant IL-2 would allow intraepithelial lymphocytes (IEL) to induce a systemic, lethal GvHR in irradiated hosts. In addition we have studied the ability of IEL to migrate into lymphoid tissues after intravenous injection and compared this with their locomotor capacity in vitro.

Intraepithelial lymphocytes (IEL) of the small intestine are in intimate contact with the enormous antigenic load of the intestinal lumen and constitute one of the largest lymphocyte populations in the body.' Furthermore, an increased proportion of IEL is found in the enteropathies of coeliac disease and cow's milk protein intolerance as well as in certain parasitic infections. ${ }^{-1}$ Although these features suggest an important role for IEL in vivo, the mechanisms by which IEL contribute to local defence, or to the pathogenesis of enteropathies are not yet clear.

In most species, the majority of IEL appear to be T cells and have the phenotype of suppressor/cytotoxic cells. ${ }^{-0}$ Furthermore IEL from experimental animals can mediate both specific and non-specific cell mediated cytotoxicity in vitro. ${ }^{\text {ItL1: }}$ Nevertheless, many of the conditions characterised by an increased proportion of IEL appear to be mediated by proliferative, rather than cytotoxic $\mathrm{T}$ lymphocytes. ${ }^{1+}$ Therefore, it is important to investigate the potential ability of IEL to exhibit proliferative $T$ cell functions. As there is controversy over the ability of IEL to proliferate in response to $\mathrm{T}$ cell mitogens or alloantigens in vitro, ${ }^{1510}$ we have studied the proliferative responses of IEL using an in vivo approach.

Address for correspondence: Dr Maria I: Balca. Western Infirmary. Glasgow (i) $16 \mathrm{NT}$.

Received for publication 19 March 1987.
The validity of this approach is supported by the fact that murine IEL can transfer a local DTH reaction in vivo $^{17}$ and can mediate a local graftversus-host $(\mathrm{GvHR})$ in the popliteal lymph node of intact hosts. ${ }^{16}$ A paradoxical finding from our previous work, however, was that intravenously injected IEL failed to induce a systemic GvHR in irradiated hosts. As these studies also showed that IEL required adherent accessory cells and lymphoid cell products to proliferate in vitro, ${ }^{\text {,t }}$ one reason for their inability to induce a systemic GvHR in irradiated mice could be because accessory factors were absent from the irradiated hosts. Alternatively, as the recirculation pathways of IEL have not been studied, their failure to induce systemic GvHR could reflect an inability to enter lymphoid tissues and encounter host alloantigens.

\section{Methods}

MICE

Adult CBA $\left(\mathrm{H}-2^{\wedge}\right)$ and $(\mathrm{CBA} \times \mathrm{BALB} / \mathrm{c}) \mathrm{F}_{1}\left(\mathrm{H}-2^{\text {hic }}\right)$ mice of both sexes were bred and maintained in the Department of Bacteriology and Immunology and were used at 8-12 weeks of age.

PREPARATION OF INTRAEPITHELIAL

LYMPHOCYTES

Intraepithelial lymphocytes were isolated and 
purified as described previously." Briefly, the small intestine was removed into cold calcium magnesium free Hanks' balanced salt solution (CMF) (Gibco) and washed through with $20 \mathrm{ml}$ fresh CMF. The Peyer's patches were then removed, the intestine slit longitudinally and divided into pieces $2-3 \mathrm{~cm}$ in length. These were washed twice in CMF and once in RPMI $/ 2 \%$ newborn calf serum (NCS) (Gibco) +100 $\mu / \mathrm{ml}$ penicillin $+100 \mu \mathrm{g} / \mathrm{ml}$ streptomycin (Gibco) before incubating for $30 \mathrm{~min}$ at $37^{\circ} \mathrm{C}$ in a shaking water bath. The gut pieces were then shaken in warm medium and the supernatants removed and stored at $4^{\circ}$. This procedure was done three times and the fragments reincubated for $30 \mathrm{~min}$ at $37^{\circ}$. The supernatant were pooled and passed over a glass wool column to remove debris before resuspending in $3 \cdot 5$ $\mathrm{ml}$ Percoll (Pharmacia, Uppsala, Sweden) of specific gravity $1 \cdot 055 \mathrm{~g}$. The suspension was layered onto $3 \mathrm{ml}$

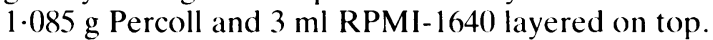
After centrifuging at $600 \mathrm{~g}$ for 15 minutes at $4^{\circ}$, the $1 \cdot 055 \mathrm{~g} / 1 \cdot 085 \mathrm{~g}$ interface was removed and washed three times in medium supplemented with 5\% NCS. The resulting suspension contained $>90 \%$ lymphocytes of $>95 \%$ viability, with the remaining cells being predominantly epithelial cells with a few eosinophils and $<1 \%$ macrophages or $B$ cells.

INDUCTION OF LETHAL, GRAFT-VERSUS-HOST DISEASE

Adult mice received $9(0)$ rads of $x$-irradiation from a $2 \cdot 2 \mathrm{MeV}$ cobalt source (beam height $100 \mathrm{~cm}$ at 125 $\mathrm{rads} / \mathrm{min}$ ) and were reconstituted within $24 \mathrm{~h}$ with $10^{7}$ IEL or spleen cells intravenously. One control group was not reconstituted in order to assess the effects of radiation itself. In some experiments (CBAX $\mathrm{BALB} / \mathrm{c}) \mathrm{F}_{1}$ host mice received $10^{7} \mathrm{CBA}$ or $\mathrm{F}_{1}$ bone marrow cells $(B M C)$ in addition to IEL, or were given daily intraperitoneal injections of 1000$) \mu$ recombinant human IL-2 (a kind gift of Biogen SA, Geneva). After irradiation, all mice received 100 mg/l neomycin sulphate (Calbiochem, La Jolla, Ca) in their drinking water.

\section{DETERMINATION OF TISSUE DISTRIBUTION OF} RADIOLABELLED CEILS

Lymphocytes were resuspended at $10^{7}$ cells $/ \mathrm{ml}$ and were labelled with $40 \mu \mathrm{Ci} / \mathrm{ml}$ of $\mathrm{Na}_{2}{ }^{{ }^{1}} \mathrm{Cr}_{2} \mathrm{O}_{4}$ by incubating at $37^{\circ} \mathrm{C}$ for 45 minutes. After washing four times in fresh medium, $3-5 \times 10 \%$ cells in $(0.2 \mathrm{ml}$ were injected intravenously into recipients which were then killed at intervals of $2,6,18,24$ hours after injection. After removal, organs were weighed and ${ }^{5} \mathrm{Cr}$-specific radioactivity measured in a gamma counter. The results were expressed as the percentage of the recovered radioactivity calculated as follows:
$\%$ Recovery $=\frac{\text { Mean organ radioactivity }(\mathrm{cpm})}{\begin{array}{l}\text { Total radioactivity in all } \\ \text { organs removed }(\mathrm{cpm})\end{array}} \times 100 \%$

COI.I.AGEN GE.I.S

Collagen was prepared as described previously." Brictly, type I collagen was extracted from rat tails with $3 \%$ acetic acid for one to two days and then dialysed against deastilled water and stored at $-20{ }^{\circ} \mathrm{C}$.

To prepare collagen gels the osmolarity and pH of a solution containing $20 \mathrm{mg}$ of collagen in $8.8 \mathrm{ml}$ were adjusted to physiological levels by mixing with $1 \mathrm{ml}$ of $10 \times$ RPMI and $200 \mu$ of 1 M IIEPES (pH 7 7 3). Two millilitres of collagen were then added to 5()$\times 13 \mathrm{~mm}$ tissue culture dishes, allowed to set for 20 minutes at room temperature and covered with medium for immediate use.

DETERMINATION OF I.OCOMOTOR CAPACITY

IN VITRO

$2 \times 10^{\prime \prime}$ lymphocytes in RPMI $+5 \%$ NCS +10()$\mu / \mathrm{ml}$ penicillin $+100 \mu \mathrm{g} / \mathrm{ml}$ streptomycin (Gibco) were layered onto fresh collagen matrices and incubated at $37^{\circ}$ overnight, before fixation with $2.5 \%$ glutaraldehyde in RPMI for 30 minutes.

The proportion of cells invading the gel was assessed by counting the cells at $10 \mu \mathrm{m}$ intervals through the gel at $\times 2(0)$ magnification using a Nikon phase contrast inverted microscope.

STATISTICAL ANAIYYSIS

Groups of means and standard deviations were compared by Student's $t$-test, while survival after irradiation was expressed as median survival times (MST), and the mortality curves were compared using Wilcoxon's Rank sum test.

\section{Results}

SYNGENEIC OR SEMIAILOGENIC BONE MARROW CELLS DO NOT ALLOW PARENTAL. IEL TO INDUCE GVHR IN IRRADIATED F, HOSTS In the first experiments, we examined whether bone marrow accessory cells of host or donor origin influenced the ability of CBA IEL to mediate GvHR in lethally irradiated $(\mathrm{CBA} \times \mathrm{BALB} / \mathrm{c}) \mathrm{F}_{1}$ mice, as has been demonstrated for other models of experimental GvHR."

All irradiated $(\mathrm{CBA} \times \mathrm{BALB} / \mathrm{c}) \mathrm{F}_{1}$ recipients of $10^{7}$ CBA spleen cells died within 7-10 days (Fig.1) and showed the characteristic features of systemic GvHR, with rapid weight loss, skin disease and diarrhoea. In contrast, mice given $10{ }^{7} \mathrm{CBA}$ IEL had a survival pattern which was identical to irradiated unreconstituted mice, confirming our previous findings. " Furthermore, none of these mice showed evidence of clinical GvHR. 


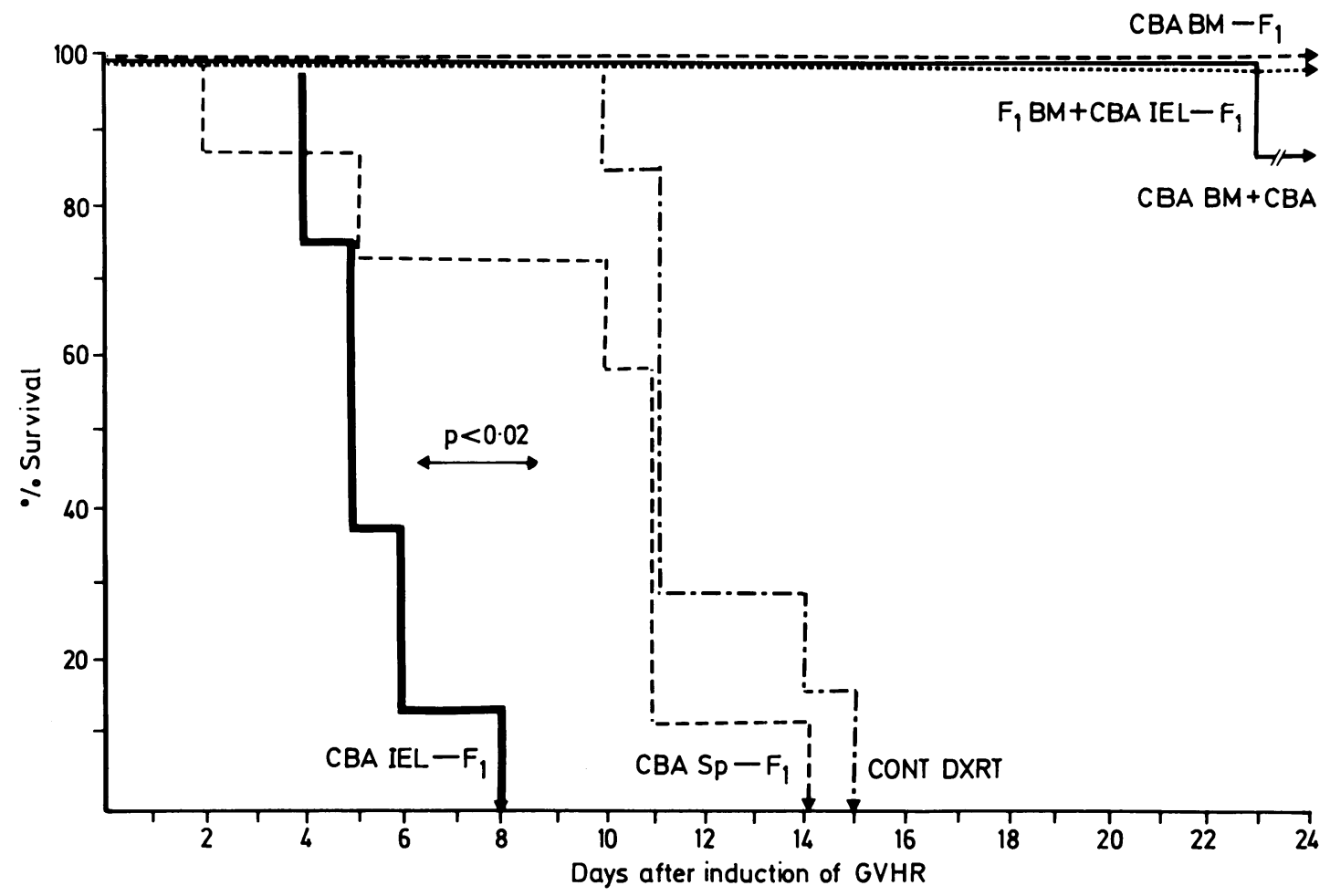

Fig. 1 Effect of bone marrow cells on the induction of $G v H R$ by $I E L$. Lethally irradiated $(C B A \times B A L B / c) F_{1}$ mice were injected with $10^{7} \mathrm{C} B A$ spleen cells or IEL to induce $G v H R$. In addition, some recipients of IEL also received $10^{7} F_{1}$ or $C B A$ $B M$ iv. Control mice were either left unreconstituted after irradiation or received $10^{7} \mathrm{CBA} B M$ cells alone. Results shown are $\%$ surviving animals at each time for $8-10$ mice/group.

Irradiated $\mathrm{F}_{1}$ mice given either $10^{7} \mathrm{CBA}$ or $\mathrm{F}_{1}$ bone marrow cells alone survived indefinitely confirming efficient haemopoietic reconstitution by the injected BMC (Fig. 1). Neither population of bone marrow cells, however, allowed CBA IEL to induce a lethal GvHR and these mice survived for up to 200 days without any clinical evidence of delayed GvHR.

EFFECTS OF RECOMBINANT INTERIEUKIN 2 ON THE INDUCTION OF GVHR BY PARENTAL IEL Proliferative responses by IEL in vitro are augmented by lymphocyte mediators ${ }^{1516}$ and interleukin 2 is known to enhance a GvHR in experimental animals. ${ }^{21}$ We therefore assessed whether concurrent administration of human rIL-2 would allow parental IEL to induce a GvHR in irradiated $(\mathrm{CBA} \times \mathrm{BALB} / \mathrm{c}) \mathrm{F}_{1}$ mice.

As before, all lethally irradiated $(\mathrm{CBA} \times$ $\mathrm{BALB} / \mathrm{c}) \mathrm{F}_{1}$ mice were given $10^{7} \mathrm{CBA}$ spleen cells died within six to eight days, with characteristic features of GvHR (Fig. 2). Daily administration of $1000 \mathrm{U}$ rIL-2 did not alter this highly aggressive form of GvHR. In this experiment, insufficient IEL were available to transfer alone to $F_{1}$ hosts, but it was clear that mice receiving IEL plus daily injection of $\mathrm{rIL}-2$ had a survival pattern which was identical to irradiated mice given rIL-2 alone. In addition, mice given IEL + rIL-2 had no clinical evidence of GvHR and survived significantly longer than spleen cell recipients. That the schedule of rIL-2 dosage used had a biological effect in recipients was confirmed by the fact that mice receiving $\mathrm{rIL}-2$ alone died more rapidly than unreconstituted, irradiated controls (Fig. 2).

RECIRCULATION OF IEL IN VIVO

As IEL were unable to induce systemic GvHR even in the presence of accessory cells or lymphokines, we went on to determine if this was because of failure of intravenously injected IEL to enter host lymphoid tissues.

CBA IEL or spleen cells were labelled with ${ }^{51} \mathrm{Cr}$ and injected iv into $(\mathrm{CBA} \times \mathrm{BALB} / \mathrm{c}) \mathrm{F}_{1}$ mice to assess their migration into tissues from two to 24 hours later. The migratory patterns of spleen cells and IEL during this period were exemplified by the findings at two and 18 hours and these results are shown in (Figs 


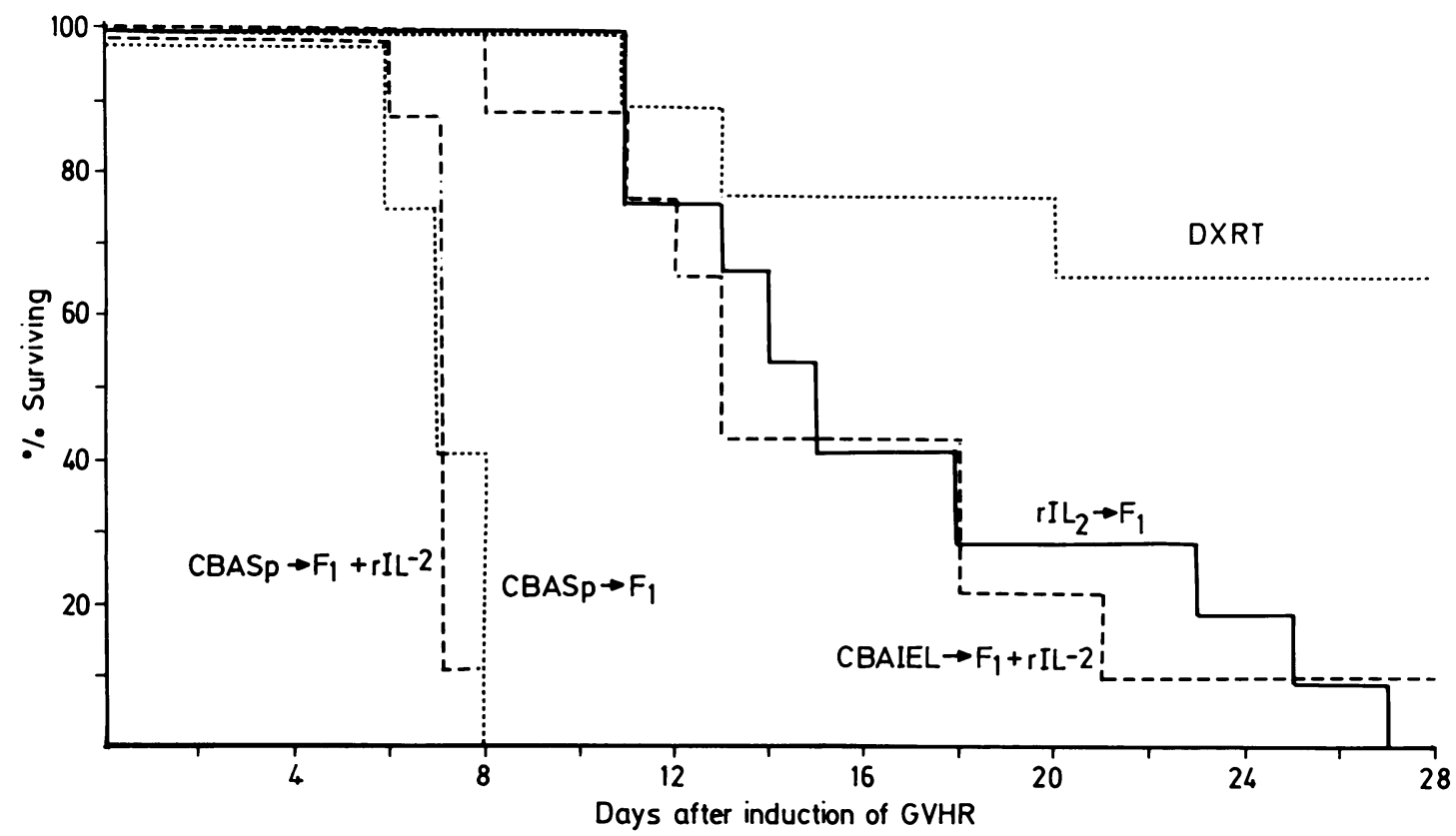

Fig. 2 Effect of human $r I L-2$ on the induction of $\left(\right.$ w $1 H R$ by IEL. Lethally irradiated $\left(C B A \times B A L\right.$ B/c) $F_{1}$ mice were injected with either $10^{7}$ CBA spleen cells or with CBA IEL alone, or with spleen cells and IEL plus daily injection of IOOOUU rIL -2. Control mice were either unreconstituted or were given rIL.-2 alone after irradiation. Results shown are \% surviving animals at each time for 6-8 mice/groups.

3 and 4). Two hours after injection, spleen cells were found predominantly in the lungs, spleen and liver, although a small, but consistent proportion were already present in the gut and lymph nodes at this time (Fig. 3). By 18 hours, less labelled cells were found in the blood and lungs and there was now a significant accumulation of cells in the lymph nodes (Fig. 4). The recovery of label from gut, spleen, liver, and kidney was similar at both time intervals.

In comparison with these findings, IEL showed a very different pattern of redistribution. Two hours after injection, the vast majority of cells were found in liver and a smaller proportion in lungs. In comparison with spleen cells, significantly fewer IEL were found in the spleen and there was virtually no accumulation in lymph nodes (Fig. 3). In parallel a larger proportion of IEL were present in the kidneys $(p<0.001)$ and liver $(p<0 \cdot(025)$ when compared with spleen cells. By 18 hours, there was a slight fall in the number of IEL found in the lungs, but there was no accumulation of IEL in lymph nodes (Fig. 4). Once again, less IEL than spleen cells were found in the spleen, while slightly more IEL were present in the blood. Interestingly, compared with spleen cells, less IEL accumulated in the small intestine at both time intervals. Finally, there was markedly more label

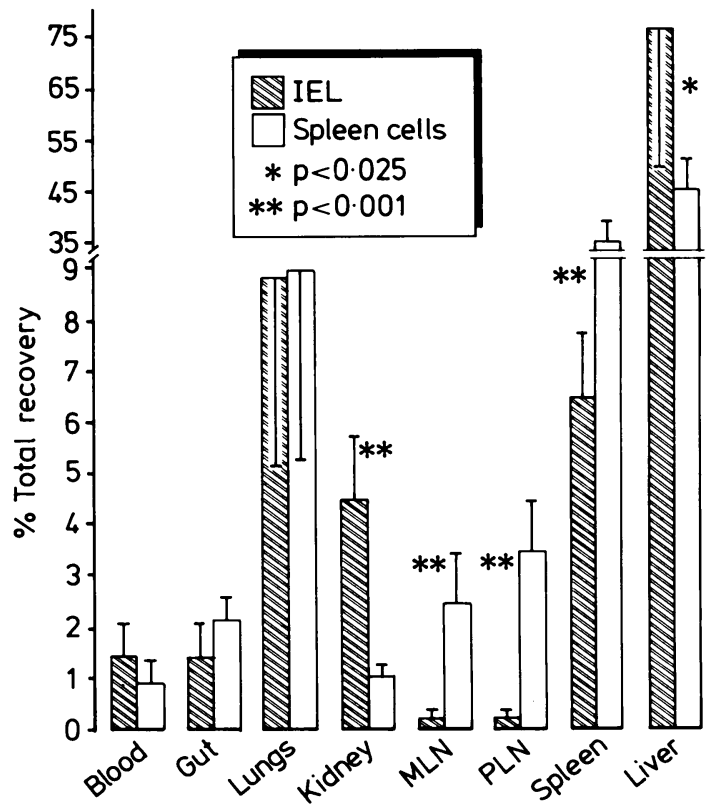

Fig. 3 In vivo migration of ' $r$-labelled IEL and spleen cells. Organ distribution of radioactivity, 2 hours after transfer of $5 \times 10^{\circ}$ syngeneic cells into $C B A$ recipients. Each bar represents the mean percentage of recovered radioactivity $\pm I$ standard deviation for 5 mice/group. 
found in the kidneys after injection of IEL. No significant accumulation of IEL was found in gut or lymph nodes at 24 hours or later (data not shown).

The defective migration of IEL was not merely a toxic effect of their isolation procedure, as IEL were fully viable when injected. In addition, MLN cells which were incubated for one hour at $37^{\circ} \mathrm{C}$ with supernatant obtained during the isolation of IEL had an identical migratory pattern to normal MLN lymphocytes (Fig. 5).

LOCOMOTOR ACTIVITY OF IEL IN VITRO

The presence of IEL within the most superficial layer of the gut suggests that these cells may be highly motile in situ. Therefore, it was important to examine if the failure to migrate in vivo was because isolation of IEL rendered them incapable of all locomotor functions. This issue was addressed by comparing the ability of IEL, spleen cells and MLN to invade collagen gels the method of choice for determining lymphocyte locomotion in vitro."2

These studies showed that IEL had an excellent locomotor capacity in vitro and migrated into collagen gels as readily as MLN and much more efficiently than spleen cells (Fig. 6). Thus, after 18 hours, $30 \%$ of IEL had invaded more than $50 \mu \mathrm{m}$

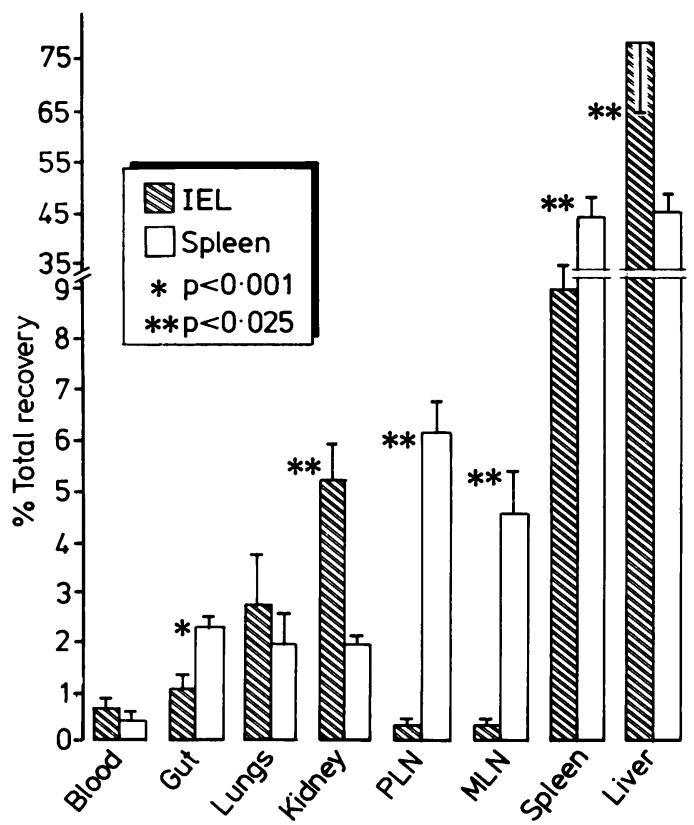

Fig. 4 In vivomigration of "Cr-labelled IEL and spleen cells. Organ distribution of radioactivity, 18 hours after transfer of $5 \times 10^{\prime \prime}$ syngeneic cells into $C B A$ recipients. Each bar represents the mean percentage of recovered radioactivity \pm 1 standard deviation for 5 mice/group. into the gel, compared with $28 \%$ and $4 \%$ of MLN and spleen cells respectively. Furthermore, very few IEL remained near the upper surface of the collagen, in contrast with the large proportion of spleen cells which showed little or no invasion (Fig. 6).

\section{Disscusion}

We have shown in this report that the inability of IEL to mediate a systemic, lethal GvHR in irradiated hosts is not reversed by the addition of bone marrow accessory cells or IL-2. Despite an excellent capacity for locomotion in vitro, however, IEL do not migrate from blood into lymphoid tissue in vivo. Thus we suggest that the failure of IEL to induce a GvHR after intravenous injection is because of their inability to enter lymphoid tissue and encounter host alloantigens.

We had initiated in vivo studies of the induction of GvHR by IEL to mediate as a way of investigating their proliferative $T$ cell functions which would not be

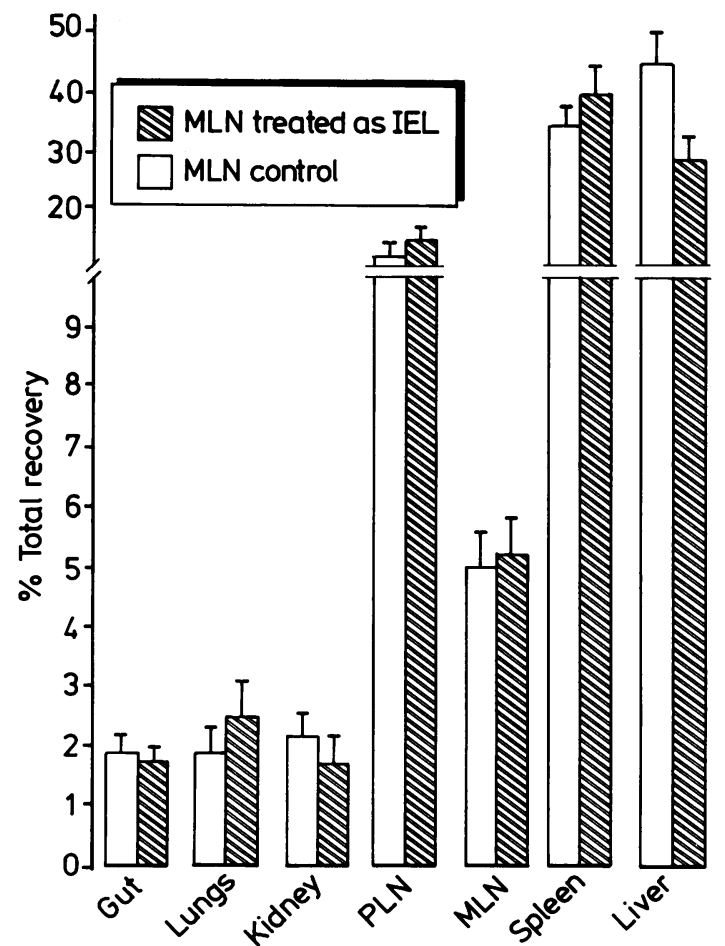

Fig. 5 Effect of the isolation procedure used to obtain IEL on the migration of MLN cells in vivo. MLN were incubated with supernatant obtained during the isolation of IEL and were treated the same way as IEL throughout the procedure. Results shown are mean \% recovered radioactivity \pm 1 standard deviation for each organ, 18 hours after transfer of $5 \times 10^{\circ}$ syngeneic MLN cells 5 mice/group. 
subject to the confusion over the responsiveness of IEL in vitro. ${ }^{15} 112:$ In the course of earlier work, we found that despite their ability to induce a local GvHR intravenously injected IEL could not mediate a systemic GvHR in irradiated mice. ${ }^{10}$ Therefore, the first experiments in the present study were designed
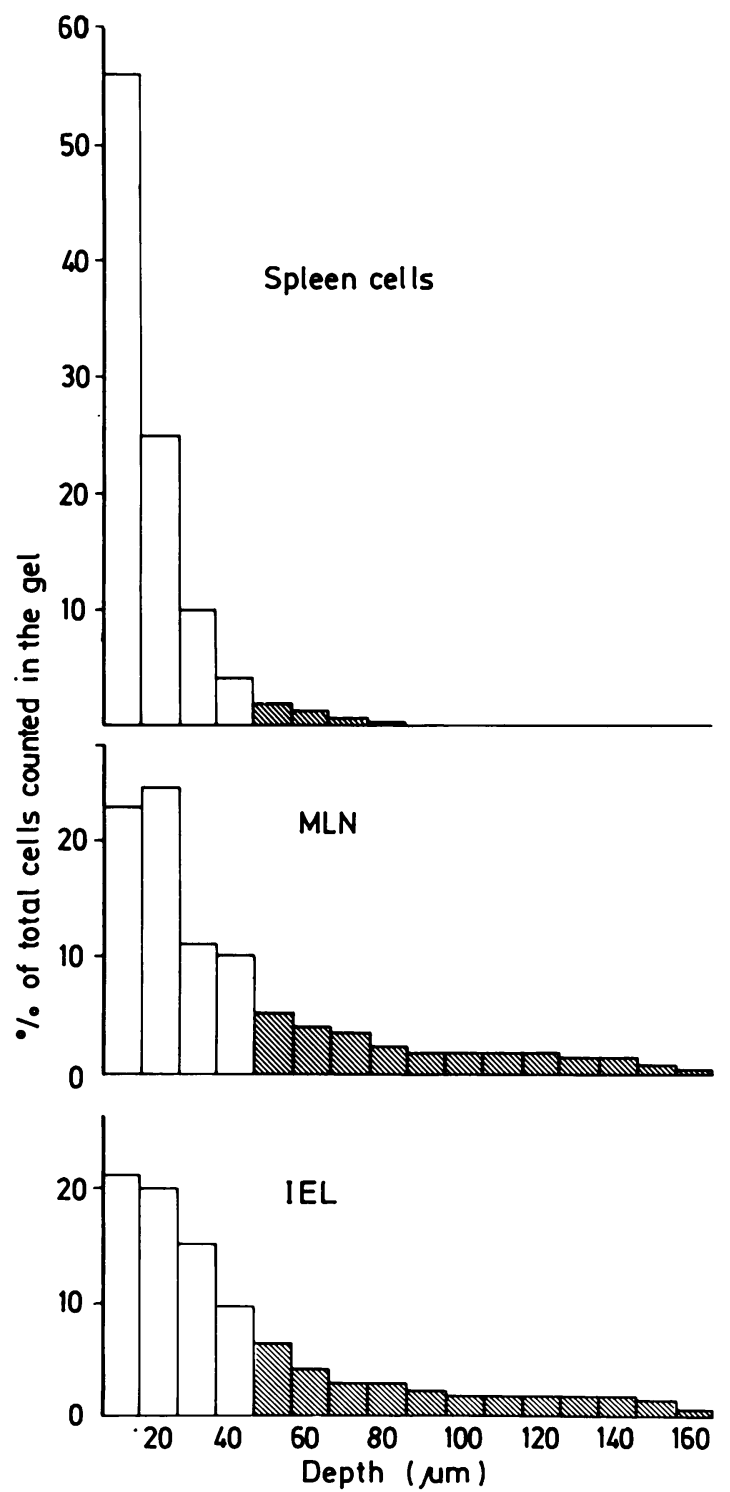

Fig. 6 Invasion of collagen gels in vitro by spleen cells, $M L N$ and IEL. $2 \times 10^{6}$ cells were allowed to migrate into gels for 18 hours and results shown are mean percentage of the total cells found in random fields at $10 \mu \mathrm{m}$ intervals throughout the gel. $50 \mu \mathrm{m}$ was chosen arbitrarily as the distance which discriminated between high and low locomotor capacity. to investigate whether this defect reflected a dependence of IEL on exogenous accessory cells and lymphocyte mediators in vivo, similar to that observed for proliferative responses in vitro."

Interleukin 2, including the preparation used here, augments the response of IEL to mitogens in vitro (McInnes and Mowat, unpublished observations). In addition, the ability of other $T$ cells to induce GvHR is enhanced by concurrent administration of IL-2 in vivo. " Bone marrow cells of both donor and host origin also increase the severity of GvHR, either by providing an additional source of donor T cells, or because of accessory cell functions such as increased presentation of host alloantigens." In the present study, however, neither addition of BM cells nor administration of IL-2 allowed IEL to induce a GvHR in irradiated hosts. Although these findings could suggest that IEL are incapable of proliferative $\mathrm{T}$ cell functions in vivo, this interpretation seemed unlikely in view of the ability of IEL to induce a local GvHR in the popliteal lymph node 15 " $"$ and to transfer a local DTH response. ${ }^{17}$ In addition, under appropriate circumstances, IEL can recognise and proliferate in response to alloantigens in vitro. ${ }^{15} 16$

For these reasons we considered the possibility that iv injected IEL could not induce systemic GvHR because of a failure to migrate from blood into lymphoid tissue in vivo. The recirculation pathways of IEL have not been detailed previously and we show here that IEL did not enter lymph nodes when injected intravenously. Furthermore, compared with spleen cells significantly fewer IEL entered the spleen and small intestine. In parallel, after transfer of IEL, more label accumulated in the liver and kidney and IEL showed slightly delayed clearance from the bloodstream. The high recovery of label found in the liver and kidney after transfer of IEL was not merely because of trapping and destruction of damaged cells, because injected IEL were of high viability, as shown by their efficient retention of ${ }^{\circ} \mathrm{Cr}$ label and by their high motility in vitro. Furthermore, we have found that heat killed cells are rapidly eliminated after transfer and do not exhibit the same redistribution in vivo as IEL (unpublished observations). One finding of interest was that as well as their failure to migrate into peripheral lymph nodes, IEL failed to enter the intestine or its lymphoid tissues. These results contrast with suggestions that IEL may be a gut homing population in vivo ${ }^{\varsigma}$ and may be able to bind high endothelial venules (HEV) from Peyer's patches (PP) in vitro. ${ }^{2}$ The single report which indicated that IEL may enter PP three to four days after transfer in vivo used poorly defined populations of IEL(s), however, and our own recent work indicates that pure IEL do not migrate to PP or other intestinal tissues at any time from one to four days 
after transfer (manuscript in preparation). In addition, it has been shown that murine IEL do not possess the MEL-14 antigen which seems to mediate binding to lymph node HEV in vivo. ${ }^{24}$ Together, these findings support our conclusion that IEL are essentially a non-recirculatory population of lymphoid cells.

Two aspects of our study may help understand the biological role of IEL in situ. Firstly, although a large proportion of IEL are granulated, ${ }^{57}$ their relationship to the other granulated cells, such as mast cells or natural killer (NK) cells, has been a matter of controversy." ${ }^{25}$ Therefore, it is of considerable interest that a recent study in rats has shown that highly purified peripheral blood, large granular lymphocytes with NK cell function exhibit a pattern of migration in vivo which is virtually identical to that we found for mouse IEL. Intraepithelial lymphocytes are capable of NK cell activity in vitro ${ }^{112}$ and together these findings suggest that at least some IEL respresent a population of granulated effector lymphocytes which are committed to cytotoxic functions in vivo. Secondly, despite their failure to recirculate in vivo, IEL were highly motile in vitro. $\mathrm{T}$ cell clones which have been activated in vitro by IL2 and T lymphocytes which are stimulated by antigen in vivo $^{2 n-29}$ also show defective recirculation in vivo. Furthermore, activated cells and lymphoblasts migrate into collagen gels more effectively than small lymphocytes.": These features support the concept that IEL may already be activated in situ.

Therefore, our study indicates that IEL may be particularly important in protecting the intestinal mucosa because many of these cells are already activated or rapidly become so after their arrival in the epithelium. Further studies of the migratory properties of IEL subpopulations in vivo and in vitro are in progress to establish which subset(s) of this heterogenous population normally show these characteristics.

We thank Dr Wendy Haston for her help in the preparation of collagen gels. Supported by MRC Project Grant Nos: G8224559CA and G8605634. Maria Baca was supported by Conacyt, Mexico.

\section{References}

1 Ferguson A. Intraepithelial lymphocytes of small intestine. Gut 1977; 18: 921.

2 Ferguson A, McClure JP. Townley RR. Intraepithelial lymphocyte counts in small intestinal biopsies from children with diarrhoea. Acta Pediatr Scand 1976; 65: 541 .

3 Phillips AD, Rice SJ, France NE, Walker-Smith JA. Small intestinal lymphocyte levels in cow's milk protein intolerance. Gut 1979; 20: $5(09$.
4 MacDonald TT, Ferguson A. Small intestinal architecture and protozoal infection in mice. Gastroenterology 1978; 74: 496

5 Guy Grand D, Griscelli C, Vassali P. The mouse gut T lymphocyte, a novel type of $T$ cell: nature, origin and traffic in mice in normal and graft versus host conditions. J Exp Med 1978; 148: 1661 .

6 Selby WS, Janossy G, Jewell DP. Immunohistological characterisation of intraepithelial lymphocytes of the human gastrointestinal tract. Gut 1981; 22: 169.

7 Parrott DMV, Tait C, MacKenzic S, Mowat AMcI. Analysis of the effector functions in different populations of mucosal lymphocytes. Ann NY Acad Sci 1983; 409: 307

8 Lyscom N, Brueton MJ. Intraepithelial, lamina propria and Peyer's patch lymphocytes of the rat small intestine: isolation and characterisation in terms of immunoglobulins markers and receptors for monoclonal antibodies. Immunology 1982; 45: 775.

9 Cref-Bensussan N, Schneeberger EE, Bhan AK. Immunohistologic and immuno-electron microscopic characterisation of the mucosal lymphocytes of human small intestine by the use of monoclonal antibodies. J Immunol 1983; 130: 2615.

10 Davies MDJ, Parrott DMV. Cytotoxic T cells in small intestinal epithelial, lamina propria and lung lymphocytes. Immunology 1981; 44: 367.

11 Tagliabue A, Luini W, Soldateschi, Boraschi D. Natural killer activity of gut mucosal lymphoid cells in mice. Eur J Immunol 1981; 1: 919.

12 Mowat AMcI, Tait RC, MacKenzie S, Davies MDJ, Parrott DMV. Analysis of natural killer effector and suppressor activity by intraepithelial lymphocytes from mouse small intestine. Clin Exp Immunol 1983; 52: 191.

13 Klein JR, Kagnoff MF. Non specific recruitment of cytotoxic effector cells in the intestinal mucosa of antigen primed mice. $J$ Exp Med 1984; 160: 1931.

14 Mowat AMcI. The immunopathogenesis of foodsensitive enteropathies. In: Newby TJ, Stokes CR, eds. Local immune responses of the gut. Florida, USA: CRC Press, 1984: 199-225.

15 Dillon SB, MacDonald TT. Functional properties of lymphocytes isolated from murine small intestinal epithelium. Immunology 1984; 52: 501 .

16 Mowat AMcI, MacKenzie S, Baca ME, Felstein MV, Parrott DMV. Functional characteristics of intraepithelial lymphocytes from mouse small intestine. II. in vitro and in vivo responses of intraepithelial lymphocytes to mitogenic and allogeneic stimuli. Immunology 1986; 58: 627 .

17 Shields JG, Parrott DMV. Appearance of DTH effector cells in murine gut mucosa. Immunology 1985; 54: 771 .

18 Davies MDJ, Parrott DMV. Preparation and purification of lymphocytes from the epithelium and lamina propria of murine small intestine. Gut 1981; 22: 481 .

19 Elsdale T, Bard J. Collagen substrata for studies on cell behaviour. J Cell Biol 1972; 54: 626.

20 Korngold R, Sprent J. Surface markers of T cell causing lethal graft versus host disease to Class I vs Class II H-2 differences. J Immunol 1985; 135: 3004.

21 Jadus MR, Peck AB. Lethal murine graft versus host disease in the absence of detectable cytotoxic T lymphocytes. Transplantation 1983; 36: 281. 
22 Shields JM, Haston W. Wilkinson PC. Invasion of collagen gels by mouse lymphoid cells. Immunology 1984: 51: 259 .

23 Wilson AD, Stokes CR. Bourne FJ. Responses of intraepithelial lymphocytes to $T$ cell mitogens: a comparison between murine and porcine responses. Immunology 1986; 58: 621.

24 Jalkanen S, Reichert A. Gallatin WA, Weissman IL. Butcher EC. Homing receptors and the control of lymphocytes migration. Immunol Rev 1986; 19: 39.

25 Ernst PB, Befus D. Bienenstock J. Leukocytes in the intestinal epithelium: an unusual immunological compartment. Immunol Today 1985; 6: 50.
26 Dailey MO, Fathman CG, Butcher EC, Pillemer E, Weissman IL. Abnormal migration of T lymphocyte clones. J Immunol 1982; 128: 2134.

27 Carroll AM. Palladino MA. Outgen H, de Sousa M. In vivo localization of eloned IL-2 dependent T' cell. C'ell Immunol 1983: 76: 69 .

28 Bookman MA, Groves ES, Matis LA. Expression of MEL-14 antigen is not an absolute requirement for dissemination to lymph nodes after adoptive transfer of murine T lymphocytes clones. J Immunol 1986; 137: 2107.

29 Issekutz TB, Webster DM. Stolz JM. Lymphocyte recruitment in vaccine virus-induced cutaneous delayed type hypersensitivity. Immunology 1986; 58: 94. 